\title{
Environmental costs of political instability in Pakistan: policy options for clean energy consumption and environment
}

Muhammad Tayyab Sohail ( $\sim$ tayyabsohail@yahoo.com )

Xiangtan University School of Public Administration https://orcid.org/0000-0002-7308-0297

Muhammad Tariq Majeed

Quaid-i-Azam University

Parvez Ahmed Shaikh

Lasbela University of Agriculture Water and Marine Sciences

Zubaria Andlib

FUUAST: Federal Urdu University of Arts Sciences and Technology

\section{Research Article}

Keywords: Political instability, Clean energy consumption, $\mathrm{CO} 2$ emissions, Pakistan

Posted Date: October 27th, 2021

DOI: https://doi.org/10.21203/rs.3.rs-843124/v1

License: (c) (i) This work is licensed under a Creative Commons Attribution 4.0 International License. Read Full License

Version of Record: A version of this preprint was published at Environmental Science and Pollution Research on November 27th, 2021. See the published version at https://doi.org/10.1007/s11356-02117646-5. 


\title{
Environmental costs of political instability in Pakistan: policy options for clean energy consumption and environment
}

\section{Muhammad Tayyab Sohail}

**Corresponding author Xiangtan University, Hunan, China. tayyabsohail@yahoo.com

Muhammad Tariq Majeed Quaid-i-Azam University, Islamabad, Pakistan. tariq@qau.edu.pk

Parvez Ahmed Shaikh

Lasbela University of Agriculture, Water and Marine Sciences, Lasbela, Pakistan. ahmed.eco@luawms.edu.pk

\section{Zubaria Andlib}

Federal Urdu University, Islamabad, Pakistan. zandlib@yahoo.com

\begin{abstract}
Using time-series data of Pakistan from 1990 to 2019, this study explores the asymmetric effects of political instability on clean energy consumption and $\mathrm{CO} 2$ emissions. The results from the traditional ARDL model show that political stability lessens environmental damage by reducing $\mathrm{CO} 2$ emissions in the long run. However, when we used the nonlinear ARDL approach we found that political instability reduces the consumption of clean energy but also leads to damage environmental quality in long run in Pakistan. While political stability increases the consumption of clean energy but also helps to improve environmental quality in the short run in Pakistan. Thus, macroeconomic policies to promote expansion in clean energy consumption will directly stimulate green economic growth and environmental quality.
\end{abstract}

Keywords: Political instability. Clean energy consumption. CO2 emissions. Pakistan.

\section{Introduction}

The persistent deteriorating environmental quality is one of the main global concerns facing the contemporary world and one of most researched problem in contemporary scholarly research. The persistent rise in greenhouse gas (GHG) emissions is generally considered the main factor behind environmental pollution and climate change (Uzar 2020; Ullah et al 2020). The pressing environmental concerns have motivated many governments to opt political choices to over come emissions. The emissions come from both developed and developing, and emerging countries. The task ahead is not easy and requires strong political decisions. 
Apparently, economic expansion and environmental performance are confronting a trade-off that is environmental loss is inevitable consequence of trailing rapid growth rates. However, if primary sources of energy such as fossil fuels and coal are switched with clean energy sources, then environmental degradation can be decoupled from growth (Majeed and Luni, 2019). Currently, environmental economists, energy experts, political scientist, domestic governments and international institutes are increasingly considering the importance of the clean sources of energy in the production process. Particularly, carbon emissions are mitigated after the Kyoto Protocol was signed in 1997 and executed in 2005. Correspondingly, United Nations (UN) has declared "clean energy" as the $17^{\text {th }}$ sustainable development goal to manage environmental problems.

Political stability and better environmental governance are necessary for the sustainable exploitation of natural resources and environmental preservation (Samimi et al., 2012). Better institutions play a conducive role in natural resource use and environmental sustainability (Abdala, 2008). In the presence of high political instability, environmental rules and regulations become less stringent and therefore, environmental pollution deteriorates the environmental quality. Al-Mulali and Ozturk (2015) examined the factors that caused environmental degradation in 14 MENA and showed that political stability is an important factor to improve the environmental quality of the region. In addition, energy consumption, urbanization, trade and industrial deteriorate the environmental quality.

The earlier studies have overlooked the political economy dynamics in exploring its effects on energy and carbon emissions though many studies have focused on the direct impact of democracy on the environmental degradation (Adams et al., 2016; Deacon, 2002; Torras and Boyce, 1998). For example, Raleigh and Urdal (2007) assert that political dynamics, particularly political regimes matter in shaping environmental outcomes. The earlier studies on the determinants of energy consumption and environmental pollution provide dissimilar results depending upon development stages (Adams and Klobodu 2017).

Adams and Klobodu (2017) extends the literature by focusing on a more comparable group of 38 African economies to explain political environmental and environmental degradation nexus over the period 1970-2011. They represent political economy by democracy and bureaucracy quality. Findings of their study suggest that both measures help to mitigate emissions in the selected African countries. Their study concluded that political institutions also play an important role in managing environmental quality including mitigation of carbon emissions.

One main argument in the literature suggests that stronger institutions help in better regulation of greenhouse gas emissions. Environmental regulation is inhibited in the presence of high corruption, red tape, bureaucratic inertia and financial mismanagement. Institutional quality removes/lowers these anti-environmental regulation factors and pave the way for the better management of the environmental quality (Panayoutou (1997). Goel and Herrala (2013) explored the direct impacts of corruption and shadow economy on carbon emissions for a panel data of 100 economies with a focus on MENA economies. They found mixed results. In general, they showed that higher levels of corruption and shadow economy are linked with lower levels of emissions. However, the opposite findings are revealed in the MENA region.

Since the beginning of 1990s, many environmentalists, energy experts and political scientists are increasingly focusing on the political aspects of environmental issues. The empirical literature also highlighted the 
democratic regimes strongly favor environmental reforms. The consecutive steam of studies largely confirmed this conclusion, with some exceptions (Midlarksy, 1998; Barrett and Graddy, 2000). This research belongs to the emerging body of the literature that emphasizes political indicators in influencing energy and environmental concerns.

The empirical literature on political economy and environmental performance has been questioned for two main deficiencies. First, political stability is not adequately measured. Second, the empirical studies provided estimates based on outdate estimation approaches that cast doubt on the reliability of the results. The theoretical underpinnings of political stability and environmental performance can be traced back the pioneering study of Grossman and Krueger (1995) which predicted an inverted U-shaped association between per capita GDP and environmental pollution. This relationship is widely known as the Environmental Kuznets Curve (EKC), and its validity is heatedly debated, however, to date the literature is not yet conclusive (Majeed and Mazhar, 2020). One likely reason could be that many studies assume the association between growth and emissions as an automated procedure. However, it is not true as Grossman and Krueger (1995) assert that the EKC will not prevail on its own, but it largely depends upon public policy rejoinders, which are grounded in public support for environmental regulation. Consequently, a new debate has emerged, which focuses on political background and stability in shaping the environmental performance.

Grossman and Krueger's claim has merits because it is high demand for clean environment that creates its own supply. However, political scientists have long noted that environmental regulations and reforms mainly rely on collective actions and smooth functioning markets. Issues associated with market failure and collection action largely hinder the path for environmental policy implementation and effectiveness. Another challenge is that the information associated to causes and effects of the problems themselves remain asymmetric. In addition, one more reason is that a socially cohesive and efficient response demands the selection of a government policy based on certain collective action mechanisms. Hence, analyzing the asymmetric impacts of political performance on environmental performance remains a crucial empirical research query and this study steps in to fill this gap.

It is widely held belief that political stable regimes favor environmental quality as the expression and mobilization of new demands supported in such a scenario. In addition, policy learning is improved in the presence of free flow of information under democratic regimes (Barret and Graddy, 2000; Midlarsky, 1998). Moreover, demand for public goods in democratic regimes is better entertained than autocratic regimes (Congleton, 1992; Deacon, 2002). In a democratic regime, the controlling group is the whole population, and the median voter concentrates on balancing out marginal costs and gains of policy action. Environmental issues stem from increased pressure on natural resources by human numbers and affluence, and political stability in terms of democracy constitutes an effective social feedback mechanism. Contrary to this, natural resources are misused in autocratic regimes as elites disproportionately controls and exploits the natural resources, thereby compromising environmental quality (Deacon, 2002). Hence political stability in terms of democracy is considered good for the environmental quality.

By contrast, the empirical literature also claims that such optimism may be misleading. Though democratic governments make more promises to manage the environmental quality, usually they do not keep their promises. 
112 Furthermore, some of the top world democracies are also viewed as laggard in environmental conservation (Battig 113 and Bernauer, 2009; Bohmelt, Boker, and Ward, 2016; Burnell, 2012). Environmental scholars have explained this puzzle considering other factors. Battig and Bernauer (2009) claim that a likely factor could be individuals 'freedom in democracies, especially in the transport sector. Some view dimensions of democracy regime, like its degree of inclusiveness (Bohmelt, Boker, and Ward, 2016), form of the electoral system (Bohmelt, Boker, and Ward, 2016), rather than democracy per se, which are helpful for environmental performance.

One strand of the literature on political institutions and environmental regulation nexus emphasizes direct as well as indirect effects of political institutions through other factors such as urbanization and trade (Goel and Herrala 2013; Adams et al 2016; Ibrahim and Law 2016). For example, Adams et al. (2016) provided evidence for Ghana that democracy lowers carbon emissions directly and indirectly though mitigating the emission impact of urbanization. In a similar vein, Ibrahim and Law (2016), provided the evidence for 44 SSA region where democracy mitigates emissions directly as well as indirectly through its interactive effect with the trade.

Another strand of the literature offers conditional effects of political factors in improving environmental quality. For example, Wawrzyniak and Doryń (2020) evaluates growth-emission nexus depending upon the institutional quality for 93 emerging and developing economies from 1995 to 2014. They employed government effectiveness and corruption as measures of institutional quality and used GMM estimation procedure. The results suggest that government effectiveness moderates the growth-emissions nexus by lowering emissions. However, their finding did not confirm the moderating role of corruption.

The discussion based aforementioned studies offer diverse effects of political economy on environmental quality. That is, political indicators can have diverse effects depending upon the type of indictor, electoral system, form of the democracy, geographical bases, and development stage of the economies. Therefore, more refined empirical evidence is required to untangle the complex relationships of political stability on clean energy and environmental quality.

This research contributes to the literature in a number of unique ways: First, to the best of authors' knowledge, this research is first of its kind that incorporates the role of political instability in clean energy and pollution models. Second, it considers diverse dimensions of political instability unlike previous studies which consider a single aspect of political instability. Third, this study employs an index of political instability. Fourth, we also consider the issue of cross-sectional dependency among selected sampled countries by employing secondgeneration panel time series analysis. Fifth, this research also explores hidden asymmetric associations between political instability, clean energy and environmental pollution by exploiting non-linear autoregressive distributive lags (NARDL) approach. The findings of this research will provide suitable police choices to manage energy and environmental concerns of the Pakistan economies and subsequently for other economies with similar profiles.

The remaining study is organized as follows: Second 2 provides a discussion of the methodology and the modelling approach. Section 3 illustrates empirical findings and their interpretation. Finally, Section 4 concludes and offers suitable policy implications. 


\section{Model and methods}

Based on the previous studies (Al-Mulali \& Ozturk 2015 and Sofuoğlu \& Ay 2020), we examine the asymmetric effects of political instability on clean energy consumption and $\mathrm{CO} 2$ emissions. Therefore, we adopt the following clean energy consumption and $\mathrm{CO} 2$ emissions model specification:

$$
\begin{aligned}
& \mathrm{CE}_{\mathrm{t}}=\alpha_{0}+\alpha_{1} \mathrm{PS}_{\mathrm{t}}+\alpha_{2} \mathrm{EG}_{\mathrm{t}}+\alpha_{3} \mathrm{FD}_{\mathrm{t}}+\mu_{\mathrm{t}}------(1) \\
& \mathrm{CO}_{2, \mathrm{t}}=\alpha_{0}+\alpha_{1} \mathrm{PS}_{\mathrm{t}}+\alpha_{2} \mathrm{EG}_{\mathrm{t}}+\alpha_{3} \mathrm{FD}_{\mathrm{t}}+\mu_{\mathrm{t}}-----(2)
\end{aligned}
$$

As can be seen, in equations (1) and (2) we have considered political stability (PS) as a key factor of clean energy consumption and environmental quality. Based on the empirical literature, we expect an estimate of $\alpha_{1}$ to be positive in equation (1), while estimates of $\alpha_{1}$ to be negative in equation (2). We used economic growth (EG) and financial development (FD) as control variables. The next stage is to change equation (1) to an error-correction modelling framework so that we can also add the short-run impacts of exogenous variables. Therefore, a new format of the equation is as:

$$
\begin{aligned}
& \Delta \mathrm{CE}_{\mathrm{t}}=\pi+\sum_{\mathrm{p}=1}^{\mathrm{n} 1} \pi_{1 \mathrm{p}} \Delta \mathrm{CE}_{\mathrm{t}-\mathrm{p}}+\sum_{\mathrm{P}=0}^{\mathrm{n} 2} \pi_{2 \mathrm{p}} \Delta \mathrm{PS}_{\mathrm{t}-\mathrm{p}}+\sum_{\mathrm{p}=0}^{\mathrm{n} 3} \pi_{3 \mathrm{p}} \Delta \mathrm{EG}_{\mathrm{t}-\mathrm{p}}+\sum_{\mathrm{p}=0}^{\mathrm{n} 4} \pi_{4 \mathrm{p}} \Delta \mathrm{FD}_{\mathrm{t}-\mathrm{p}}+\beta_{1} \mathrm{CE}_{\mathrm{t}-1}+ \\
& \beta_{2} \mathrm{PS}_{\mathrm{t}-1}+\beta_{3} \mathrm{EG}_{\mathrm{t}-1}+\beta_{4} \mathrm{FD}_{\mathrm{t}-1}+\mu_{\mathrm{t}}------- \text { (3) }
\end{aligned}
$$

$$
\begin{aligned}
& \Delta \mathrm{CO}_{2, \mathrm{t}}=\pi+\sum_{\mathrm{p}=1}^{\mathrm{n} 1} \pi_{1 \mathrm{p}} \Delta \mathrm{CO}_{2, \mathrm{t}-\mathrm{p}}+\sum_{\mathrm{P}=0}^{\mathrm{n} 2} \pi_{2 \mathrm{p}} \Delta \mathrm{PS}_{\mathrm{t}-\mathrm{p}}+\sum_{\mathrm{p}=0}^{\mathrm{n} 3} \pi_{3 \mathrm{p}} \Delta \mathrm{EG}_{\mathrm{t}-\mathrm{p}}+\sum_{\mathrm{p}=0}^{\mathrm{n} 4} \pi_{4 \mathrm{p}} \Delta \mathrm{FD}_{\mathrm{t}-\mathrm{p}}+\beta_{1} \mathrm{CO}_{2, \mathrm{t}-1}+ \\
& \beta_{2} \mathrm{PS}_{\mathrm{t}-1}+\beta_{3} \mathrm{EG}_{\mathrm{t}-1}+\beta_{4} \mathrm{FD}_{\mathrm{t}-1}+\mu_{\mathrm{t}}--------(4)
\end{aligned}
$$

Equation (2) is assessed by the OLS, short-run impacts are noted in the estimates of "delta" variables and long-run effects are noted by the estimates of $\beta_{2}-\beta_{4}$ normalized on $\beta_{1}$. The linear ARDL specification is first time introduced by Pesaran et al. (2001) and becomes the workhorse of time series modelling. For the validity of long-run coefficient estimates to be important, Pesaran et al. (2001) suggest F test and ECM or t-test. Since macroeconomic variables could be a combination of $\mathrm{I}(0)$ and $\mathrm{I}(1)$, both tests have new critical values in estimation. We extended the empirical literature so that we can explore the asymmetry analysis. The modification in linear modelling, first time introduced by Shin et al. (2014). The concept of the partial sum is used to decompose ( $\Delta \mathrm{PS}$ ) into two new timeseries as follows:

$$
\begin{aligned}
& \mathrm{PS}^{+}{ }_{\mathrm{t}}=\sum_{\mathrm{n}=1}^{\mathrm{t}} \Delta \mathrm{PS}^{+}{ }_{\mathrm{t}}=\sum_{\mathrm{n}=1}^{\mathrm{t}} \max \left(\Delta \mathrm{PS}^{+}{ }_{\mathrm{t}}, 0\right) \\
& \mathrm{PS}^{-}{ }_{\mathrm{t}}=\sum_{\mathrm{n}=1}^{\mathrm{t}} \Delta \mathrm{PS}^{-}{ }_{\mathrm{t}}=\sum_{\mathrm{n}=1}^{\mathrm{t}} \min \left(\Delta \mathrm{PS}^{-}{ }_{\mathrm{t}}, 0\right)
\end{aligned}
$$

Where $\mathrm{PS}^{+}{ }_{\mathrm{t}}$ reveals the partial sum of positive shock, infers political stability and $\mathrm{PS}^{-}{ }_{\mathrm{t}}$ reflects the partial sum of negative shock, infers political instability. Two new time series are used to replace $\mathrm{PS}_{\mathrm{t}}$ in equation (3 and 4) to arrive at: 
$\Delta \mathrm{CE}_{\mathrm{t}}=\pi+\sum_{\mathrm{p}=1}^{\mathrm{n} 1} \pi_{1 \mathrm{p}} \Delta \mathrm{CE}_{\mathrm{t}-\mathrm{p}}+\sum_{\mathrm{P}=0}^{\mathrm{n} 2} \pi_{2 \mathrm{p}} \Delta \mathrm{PS}_{\mathrm{t}-\mathrm{p}}^{+}+\sum_{\mathrm{p}=0}^{\mathrm{n} 3} \pi_{3 \mathrm{p}} \Delta \mathrm{PS}^{-}{ }_{\mathrm{t}-\mathrm{p}}+\sum_{\mathrm{P}=0}^{\mathrm{n} 4} \pi_{4 \mathrm{p}} \Delta \mathrm{EG}_{\mathrm{t}-\mathrm{p}}+$

$\sum_{\mathrm{p}=0}^{\mathrm{n} 5} \pi_{5 \mathrm{p}} \Delta \mathrm{FD}_{\mathrm{t}-\mathrm{p}}+\beta_{1} \mathrm{CE}_{\mathrm{t}-1}+\beta_{2} \mathrm{PS}_{\mathrm{t}-1}^{+}+\beta_{3} \mathrm{PS}^{-}{ }_{\mathrm{t}-1}+\beta_{4} \mathrm{EG}_{\mathrm{t}-1}+\beta_{5} \mathrm{FD}_{\mathrm{t}-1}+\mu_{\mathrm{t}}$

$\Delta \mathrm{CO}_{2, \mathrm{t}}=\pi+\sum_{\mathrm{p}=1}^{\mathrm{n} 1} \pi_{1 \mathrm{p}} \Delta \mathrm{CO}_{2, \mathrm{t}-\mathrm{p}}+\sum_{\mathrm{P}=0}^{\mathrm{n} 2} \pi_{2 \mathrm{p}} \Delta \mathrm{PS}^{+}{ }_{\mathrm{t}-\mathrm{p}}+\sum_{\mathrm{p}=0}^{\mathrm{n} 3} \pi_{3 \mathrm{p}} \Delta \mathrm{PS}^{-}{ }_{\mathrm{t}-\mathrm{p}}+\sum_{\mathrm{P}=0}^{\mathrm{n} 4} \pi_{4 \mathrm{p}} \Delta \mathrm{EG}_{\mathrm{t}-\mathrm{p}}+$

$\sum_{\mathrm{p}=0}^{\mathrm{n} 5} \pi_{5 \mathrm{p}} \Delta \mathrm{FD}_{\mathrm{t}-\mathrm{p}}+\beta_{1} \mathrm{CO}_{2, \mathrm{t}-1}+\beta_{2} \mathrm{PS}^{+}{ }_{\mathrm{t}-1}+\beta_{3} \mathrm{PS}_{\mathrm{t}-1}^{-}+\beta_{4} \mathrm{EG}_{\mathrm{t}-1}+\beta_{5} \mathrm{FD}_{\mathrm{t}-1}+\mu_{\mathrm{t}}$

Equation (6 and 7) is generally referred and known as a nonlinear or asymmetric ARDL model, whereas Eq. (3 and 4) is mentioned as the linear or symmetric ARDL model. Shin et al. (2014) also used the same estimation method and similar diagnostic tests. The conventional ARDL diagnostic tests are also applied in the asymmetric model. For nonlinear ARDL, we also test a few additional asymmetry hypotheses. First, if two partial sum indicators have different lag orders in the short term which is a signal of short-term asymmetry. Second, at similar lags in two partial sum series any given lag order $p$, if coefficient estimates are different which confirm the short-run asymmetry through the Wald test. Finally, the response of the $\mathrm{CO} 2$ emissions to political stability changes will be nonlinear in the long run if the Wald test nullified the hypothesis of $-\beta_{2} / \beta_{1}=-\beta_{3} / \beta_{1}$.

We have two dependent variables in this study, i.e clean energy use and $\mathrm{CO} 2$ emissions as proxies to assess the impact of political stability on clean energy and environmental quality. Whereas our independent variable is political stability, but financial development and economic growth are used as control variables. We obtained all datasets from World Bank, except political stability. The variable description is given in Table 1.

Table 1: Definitions and descriptive statistics

\begin{tabular}{llll}
\hline Variable & Symbol & Definition & Sources \\
\hline Clean energy & CE & Alternative and nuclear energy (\% total energy use) & World Bank \\
$\begin{array}{llll}\text { Carbon dioxide } \\
\text { emissions }\end{array}$ & CO2 & Carbon dioxide emissions (kilotons) & World Bank \\
$\begin{array}{l}\text { Political stability } \\
\text { Economic growth }\end{array}$ & PS & The political stability index ranges from 0 to 100 & ICRG \\
Financial development & FD & GDP growth (annual \%) & World Bank \\
\hline
\end{tabular}

\section{Empirical findings and discussion}

The prime objective of the present study is to assess the asymmetric impacts of political stability on clean energy and $\mathrm{CO} 2$ emissions in the case of Pakistan. To specify the appropriate model, the first step is to check the stationarity of the data by using Phillips-Perron (PP) and Augmented Dickey-Fuller (ADF) unit root test statistics. In Table 2, ADF tests statistics values reveal that CE, CO2 emissions, PS are non-stationary at I (0) and thus they become stationary at $\mathrm{I}(1)$, i.e first difference. However, the rest of the two variables namely, EG and FD are stationary at I (0). After checking the stationarity of the included variables we can infer that we can apply the NARDL approach for the empirical estimation. Meanwhile, if we carefully observe the PP statistics values, then we can find out that CE, PS, and FS are non-stationary at $\mathrm{I}(0)$ but they are stationary at $\mathrm{I}(1)$. The rest of the two variables are stationary at I $(0)$. 
214 Table 2: Unit root tests

\begin{tabular}{lllllll}
\hline & \multicolumn{2}{l}{ ADF test statistic } & \multicolumn{3}{l}{ PP test statistic } \\
\hline Variables & Level & 1st difference & Decision & Level & 1st difference & Decision \\
\hline $\mathrm{CE}$ & 1.413 & $3.538^{* *}$ & $\mathrm{I}(1)$ & 2.511 & $7.476 * *$ & $\mathrm{I}(1)$ \\
$\mathrm{CO}_{2}$ & -0.144 & $-1.791^{*}$ & $\mathrm{I}(1)$ & $-4.173^{* * *}$ & & $\mathrm{I}(0)$ \\
$\mathrm{PS}$ & -1.531 & $-5.101^{* * *}$ & $\mathrm{I}(1)$ & -2.219 & $-5.372^{* * *}$ & $\mathrm{I}(1)$ \\
$\mathrm{EG}$ & $-3.387^{* * *}$ & & $\mathrm{I} 0)$ & $-3.318^{* *}$ & & $\mathrm{I}(0)$ \\
$\mathrm{FD}$ & $-2.630^{* * *}$ & & $\mathrm{I}(0)$ & -1.983 & $-5.904 * * *$ & $\mathrm{I}(1)$ \\
\hline
\end{tabular}

Table 3 depicts the empirical estimated results of ARDL and NARDL models to quantify the asymmetric and non-asymmetric impacts of political stability on clean air and $\mathrm{CO} 2$ emissions in Pakistan. First, we will discuss the estimated results of the ARDL model and then we will explain the NARDL model for clean air and also for CO2 emissions. In the first column of Table 3, we have reported the empirical coefficients of the ARDL model for the clean energy model. We observe that the coefficient of political stability is positive and significant at 5 percent. It implies that a 1 percent increase in political stability will increase the use of cleaner energy by 2.987 percent in the case of Pakistan. We can infer that political stability is positively influencing the use of cleaner energy. On the other hand, the one-year lag value of political stability is also positively associated with the use of cleaner energy in the case of Pakistan. It is indicated from Table 3 that in the short run one 1 percent increase in the one-year lag value of political stability is causing a 2.130 percent increase in the use of clean energy. However, we could not find a significant difference between the current and lag value of political instability on the use of clean energy.

Next, we have concluded from the empirical results that economic growth is positively associated with the use of clean energy in Pakistan in the short run. In the same context, a 1 percent increase in economic growth leads to a 0.101 percent increase in the use of clean energy and it is significant at 5 percent. Meanwhile, the one-period lag of economic growth is also positively and significantly associated with the use of clean energy in Pakistan. It elaborates that with an increase in GDP, the economy invests in cleaner and environmentally friendly technologies. Our results in line with previous studies such as Ahmed and Long (2013), Javid and Sharif (2016), and Khan and Ullah (2019). Similarly, we have found that financial development is negatively associated with the use of clean energy in Pakistan. According to the empirical estimates for the short run, we can observe that a 1 percent increase in financial development is leading to a 1.290 percent decrease in the use of cleaner energy in Pakistan. Our results are consistent with the previous literature on the impact of financial development on environmental quality, for example, Zhang (2011); Ozturk and Acaravci (2013); Dogan and Turkekul (2016); Lahiani (2020) and Shoaib et al. (2020). These studies are of the view that financial development is causing a deterioration in overall environmental quality. Overall, we can justify the negative impacts of financial development through three effects namely, capitalization effect, technology effects, and income effect.

Next, we will explain the long-run coefficients of the clean energy model. We observe that in the long run,

242 political stability is negatively associated with the use of clean energy however it is insignificant. In a similar study, 243 Carlson and Lundström (2003) also found the insignificant impact of political stability on environmental quality.

244 Similarly, Sarkodie and Adams (2018) also explained the insignificant association between political stability and 
environmental degradation in South Africa. Furthermore, economic growth is positively associated with the use of cleaner energy, even though it is not significant. In the same context, Sharma (2011) also found a positive and insignificant impact of GDP on environmental quality for the sample of 69 countries. Financial development is also negatively associated with the use of cleaner energy but it is also insignificant. Few other studies in literature such as Dogan and Turkekul (2015) and Abid (2016) also found an insignificant association between these two variables of interest.

Now we will discuss the empirical results of the ARDL model for the $\mathrm{CO} 2$ model. We found a few very interesting insights in this regard. First, we will explain the short-run empirical estimates of the ARDL model. We can infer that in the short run the political stability is negatively associated with $\mathrm{CO} 2$ emissions but it is insignificant. Meanwhile, we have included a one-period lag value of political stability, which is positively influencing the use of $\mathrm{CO} 2$ emissions but it is insignificant. Our results are consistent with the previous literature, where different researchers found an insignificant relationship between political instability and $\mathrm{CO} 2$ emissions, for example, Carlsson and Lundström (2003) and Sarkodie and Adams (2018). Meanwhile, in the short run, economic growth is positively and significantly associated with the level of $\mathrm{CO} 2$ emissions. It implies that a 1 percent increase in economic growth will lead to the 0.006 percent increase in $\mathrm{CO} 2$ emissions and it is significant at 5 percent. We found immense literature on the positive and significant impact of GDP on CO2 emissions (Sharma, 2011; Kasperowicz,2015; Ullah et al,2020). Furthermore, the one-period lag of economic growth is negatively and significantly associated with the level of $\mathrm{CO} 2$ emissions in Pakistan.

In the previous literature on the impact of financial development on $\mathrm{CO} 2$ emissions, we observe that financial development can also spur manufacturing activities, therefore, consider to be the most important source to upsurge the $\mathrm{CO} 2$ emissions. In the present study, we can conclude from the short-run empirical analysis that financial development is positively associated with the level of emission in the short run and it is significant at $5 \%$. Meanwhile, a one-year lag value of financial development is negatively influencing the $\mathrm{CO} 2$ emissions and it is significant at 10 percent.

In the long run, we observe that political stability is negatively and significantly associated with $\mathrm{CO} 2$ emissions i.e 1 percent increase in political stability, in the long run, causes an increase in $\mathrm{CO} 2$ emission by 1.267 percent and it is significant at 10 percent. According to the previous literature political stability is one of the most prominent factors to improve environmental quality by increase clean energy consumption. In presence of political 273 stability, the government can impose strict environmental regulations which in turn help to improve the 274 environmental quality in the economy. Our results are consistent with previous literature, for example, Gani (2012); 275 Lau et al. (2014), and Bhattacharya et al. (2017). Abid (2016) explained that political stability is positively 276 influencing the environmental quality in the case of selected Sub-Saharan African countries. Al-Mulali and Ozturk, 277 (2015) examined the impact of political stability on environmental quality in the case of the MENA region and 278 concluded that political stability is helping to improve the environmental quality in these economies. Similarly, 279 economic growth is also positively surging the level of $\mathrm{CO} 2$ emissions but it is not significant in our ARDL model. 280 On the other hand, our financial development is positively and significantly causing an increase in $\mathrm{CO} 2$ emissions 281 and the coefficient is significant at 5 percent. We found immense literature which is supporting the positive 
association between financial development and $\mathrm{CO} 2$ emissions. For example, Komal and Abbas (2015) assessed that financial development is positively associated with $\mathrm{CO} 2$ emissions in the case of Pakistan. Besides, Khan et al.

284 (2020) revealed that financial development is upsurging the level of CO2 emissions. Shahzad et al. (2017) applied

285 the ARDL test found a long-run and positive association between financial development and CO2 emissions in the case of the Pakistani economy. Abbasi and Riaz, (2016) also supported the positive impact of the financial development on $\mathrm{CO} 2$ emission.

We have explained the results of diagnostic tests in Table 3. First of all, $F$ tests' values are confirming the presence of co-integration for the clean energy model as well as the $\mathrm{CO} 2$ emission model. Furthermore, to know about the existence of serial correlation in our estimated models we have applied a Lagrange multiplier test. Its coefficient is insignificant in both of the models. Therefore we can conclude that there is no serial correlation in these estimated models. At the same time by looking at the values of the RESET test we can conclude that there are no model specification errors in our estimated models. In the end, we are concerned with the stability of the parameters in both of the estimated models. Thus we have applied two tests, i.e. CUSUM test and the CUSUMSQ test. Here "S" implies stability whereas "US" implies instability. However, we can see in Table 3 that both of our models are indicating the stability of the parameters.

Table 3: ARDL and NARDL of Clean energy consumption and $\mathrm{CO2}$

\begin{tabular}{|c|c|c|c|c|c|c|c|c|}
\hline & \multicolumn{4}{|c|}{ Clean energy model } & \multicolumn{4}{|l|}{ CO2 model } \\
\hline & \multicolumn{2}{|l|}{ ARDL } & \multicolumn{2}{|l|}{ NARDL } & \multicolumn{2}{|l|}{ ARDL } & \multicolumn{2}{|l|}{ NARDL } \\
\hline & & $t-$ & & t- & & t- & & t- \\
\hline & Coefficient & Statistic & Coefficient & Statistic & Coefficient & Statistic & Coefficient & Statistic \\
\hline \multicolumn{9}{|l|}{ Short-run } \\
\hline $\mathrm{D}(\mathrm{PS})$ & $2.987^{* *}$ & 3.794 & & & -0.045 & -0.761 & & \\
\hline$D(P S(-1))$ & $2.130 * *$ & 1.972 & & & 0.079 & 1.381 & & \\
\hline$D(P S(-2))$ & -0.845 & -0.863 & & & & & & \\
\hline$D(P S(-3))$ & -1.352 & -1.591 & & & & & & \\
\hline D(PS_POS) & & & $1.201^{*}$ & 1.736 & & & $-0.197^{*}$ & -1.731 \\
\hline D(PS_POS(-1)) & & & $2.768^{* *}$ & 2.318 & & & 0.189 & 1.315 \\
\hline D(PS_POS(-2)) & & & $-2.479 * *$ & -3.038 & & & -0.008 & -0.066 \\
\hline D(PS_NEG) & & & $1.594^{*}$ & 1.902 & & & 0.027 & 0.173 \\
\hline $\mathrm{D}\left(\mathrm{PS} \_N E G(-1)\right)$ & & & -1.449 & -0.887 & & & -0.138 & -0.870 \\
\hline D(PS_NEG(-2)) & & & $4.181^{* *}$ & 2.976 & & & & \\
\hline $\mathrm{D}(\mathrm{EG})$ & $0.101^{* *}$ & 3.146 & $0.158^{* *}$ & 4.470 & $0.006^{* *}$ & 2.005 & $0.011^{* *}$ & 2.628 \\
\hline $\mathrm{D}(\mathrm{EG}(-1))$ & $0.092 * *$ & 2.248 & & & $-0.011 * *$ & -3.462 & $-0.021 * *$ & -4.822 \\
\hline $\mathrm{D}(\mathrm{FD})$ & -1.290 & -1.566 & $-1.990 * *$ & -3.420 & $0.255^{* *}$ & 3.859 & $0.287^{* *}$ & 3.154 \\
\hline $\mathrm{D}(\mathrm{FD}(-1))$ & & & $-1.436^{*}$ & -1.776 & $-0.130 *$ & -1.814 & $-0.165^{*}$ & -1.728 \\
\hline $\mathrm{D}(\mathrm{FD}(-2))$ & & & -1.049 & -1.450 & & & 0.110 & 1.211 \\
\hline \multicolumn{9}{|l|}{ Long-run } \\
\hline PS & -18.58 & -0.437 & & & $-1.267^{*}$ & -1.869 & & \\
\hline PS_POS & & & -0.247 & -0.438 & & & -0.381 & -0.198 \\
\hline PS_NEG & & & $-0.778^{*}$ & -1.771 & & & $1.202^{*}$ & 1.722 \\
\hline EG & 0.442 & 0.502 & $0.200 * *$ & 4.635 & 0.118 & 0.883 & 0.242 & 0.744 \\
\hline
\end{tabular}




\begin{tabular}{|c|c|c|c|c|c|c|c|c|}
\hline FD & -11.04 & -0.480 & 0.267 & 0.634 & $5.671^{* *}$ & 2.004 & $4.809 *$ & 1.669 \\
\hline C & 107.32 & 0.462 & 1.382 & 0.858 & 0.304 & 0.047 & -3.740 & -0.174 \\
\hline \multicolumn{9}{|c|}{ Diagnostic stat } \\
\hline F-test & $3.977^{*}$ & & 1.971 & & $10.07 * *$ & & $10.22^{* *}$ & \\
\hline $\mathrm{ECM}(-1)$ & -0.072 & 0.395 & $-0.787^{* *}$ & -5.411 & $-0.346 * *$ & 2.373 & $-0.681^{*}$ & 1.678 \\
\hline LM & 0.975 & & 1.146 & & 1.184 & & 1.748 & \\
\hline R-set & 1.167 & & 0.182 & & 1.418 & & 0.085 & \\
\hline CUSUM & $S$ & & $\mathrm{~S}$ & & $S$ & & $\mathrm{~S}$ & \\
\hline CUSUMsq & $S$ & & $S$ & & S & & US & \\
\hline Wald-SR & & & $3.982 * *$ & & & & 1.987 & \\
\hline Wald-LR & & & 2.123 & & & & $4.987^{* *}$ & \\
\hline
\end{tabular}

Note: Significance levels: **, 5\%; and *, $10 \%$.

Now we will explain the asymmetric effects of political instability on clean energy use and $\mathrm{CO} 2$ emissions in the case of Pakistan. First, we will explain the short-run coefficients of the clean energy use model. As column 2 of Table 3 reveals that in the short run, a positive shock in political stability is positively associated with the use of clean energy and it is significant at 10 percent. Moreover, a negative shock in political stability is also positively and significantly associated with clean energy use in Pakistan. The empirical results are supporting the asymmetries in the relationship between political stability and the use of clean energy in the case of Pakistan. In the same regard, Purcel (2019) explained the relationship between political stability and environmental degradation in the case of lower and middle-income countries and concluded an inverted $U$ shape relationship. Meanwhile, a positive shock in the one-year lag value of political stability is also positively associated with the use of clean energy and it is significant at 5 percent. We can infer from our empirical analysis that economic growth is positively influencing the use of clean energy in the case of Pakistan. The empirical results are supported by previous literature, Nasir and Rehman (2011); Ahmed and Long (2013); Javid \& Sharif (2016) and Khan \& Ullah (2019). We can infer from our empirical estimation that financial development exerting a negative influence on the use of clean energy. We found immense evidence from the existing literature in this regard. For instance; Haseeb et al. (2018), Pata (2018), Gokmenoglu and Sadeghieh (2019).

In the long run, a positive shock in political stability is negatively influencing the use of clean energy; however, it is not significant. Similarly, a negative shock in political stability is negatively and significantly associated with the use of clean energy. Also, Rizk and Slimane (2018) indicated that political stability can lower $\mathrm{CO} 2$ emissions. In the case of economic growth we have observed that in the long run, economic growth is exerting a positive influence on the use of clean energy. Ahmed and Long (2013) and Javid and Sharif (2016) also found the same evidence in case of Pakistan. In the long run the financial development is negatively and insignificantly associated with the use of clean energy. On the same lines, Ding et al. (2018) also found an insignificant association between financial development and CO2 emissions for China and 219 trading partners for the time period 2004 to 2014.

Next, we will discuss the asymmetric impacts of political stability on $\mathrm{CO} 2$ emissions in the case of Pakistan. The empirical results of the short-run estimates of the NARDL model reveal that a positive shock in political stability is negatively associated with $\mathrm{CO} 2$ emissions and also a negative shock in political stability is 
positively associated with the level of $\mathrm{CO} 2$ emissions. Therefore in the case of Pakistan, we can infer the presence of asymmetries between political stability and $\mathrm{CO} 2$ emissions. Similarly in the short run, financial development is a prominent source of $\mathrm{CO} 2$ emissions in our empirical analysis. As indicated by our empirical analysis a positive shock in financial development is causing an increase in $\mathrm{CO} 2$ emissions.

In the long run, a positive shock in political stability is exerting a negative influence on $\mathrm{CO} 2$ emissions and a negative shock in political stability is causing an upsurge in $\mathrm{CO} 2$ emissions. We found strong evidence of asymmetries in the said relationship in the case of Pakistan. According to our empirical analysis economic growth is positively associated with $\mathrm{CO} 2$ emissions in the long run. There is immense literature available in the same context, for instance, Tamazian et al. (2009); Shahbaz et al. (2013) and Dogan and Seker (2016). Financial development is proved to be an important determinant of an increase in $\mathrm{CO} 2$ emissions. Our results are consistent with Ozturk and Acaravci (2013) and Farhani and Ozturk, (2015). These studies are of the view that financial development is actually giving a way to enter heavy industries into the economy and therefore up surging the $\mathrm{CO} 2$ emissions.

In the end, we will discuss the results of diagnostic tests, in the case of NARDL models for clean energy use and $\mathrm{CO} 2$ emissions. The $\mathrm{F}$ test values validate the joint significance of long run estimates for both models i.e clean energy and $\mathrm{CO} 2$ emissions. Besides, the critical values of the $\mathrm{F}$ test also confirm the existence of cointegration in both models. To check the serial correlation, we have applied the LM test and by looking at the estimated coefficients of LM tests we could not find any evidence of serial correlation. Besides, to check the correct model specification, and also stability of the parameters we have applied three tests, RESET CUSUM, and CUSUMsq tests. These tests validate the correct model specification as well as parameters stability. According to the estimated values of the goodness of fit measures tests, we can infer that models are well fitted. We applied the Wald test to confirm the asymmetries in the model. We can infer from the estimated coefficients of Wald tests that both the short 
Figure 1: Asymmetric dynamic multipliers effects of political stability on clean energy consumption

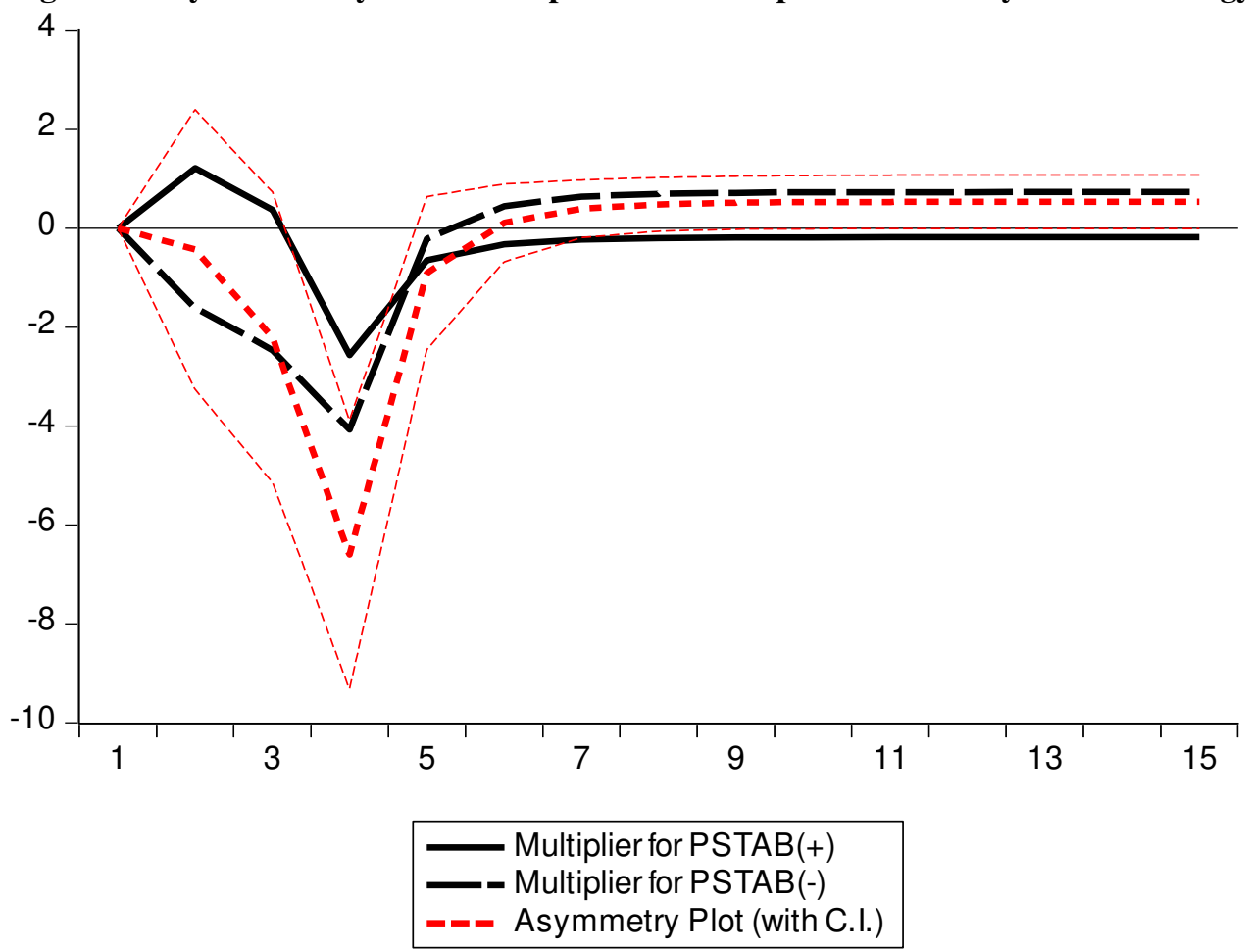

Figure 2: Asymmetric dynamic multipliers effects of political stability on the $\mathrm{CO2}$ model

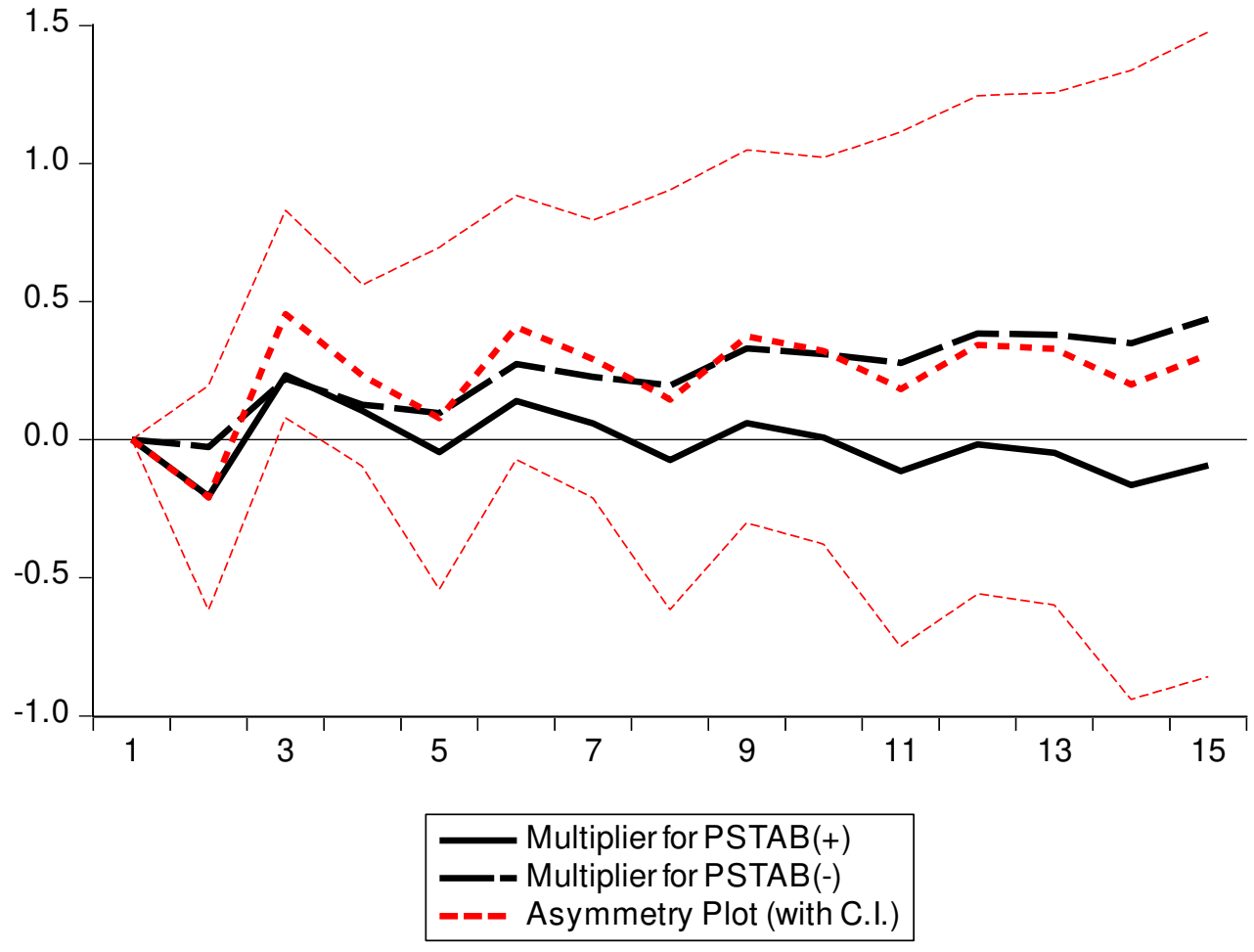




\section{Conclusion and implications}

The key purpose of this paper is to investigate the asymmetric impact of political instability on clean energy consumption and $\mathrm{CO} 2$ emissions in Pakistan. To achieve this objective, the time-series data NARDL approach is employed for the period 1990-2019. The findings of the study have revealed that political stability and instability have a positive and significant impact on clean energy consumption in short run. However, the short-run effects of political stability lower $\mathrm{CO} 2$ emissions in Pakistan; this finding is in accordance with the theory. However, $\mathrm{CO} 2$ emissions in Pakistan is not affected by the political instability in short-run. Moreover, in long-run, political stability did not show any significant and robust effects on clean energy consumption and $\mathrm{CO} 2$ emissions. Conversely, in long-run, political instability has only revealed negative and significant effects on clean energy consumption but it has a positive impact on $\mathrm{CO} 2$ emissions in Pakistan. The asymmetric results show that policy instability has a more dramatic and robust impact on clean energy consumption and $\mathrm{CO} 2$ emissions than political stability. This finding is consistent with Al-Mulali \& Ozturk (2015), who argues that political instability leads to lower public-private clean energy investments and, hence, lower clean energy consumption and more carbon emissions.

Based on empirics, some specific implications can be made for the deployment of clean energy and environment. The institution should reduce the conflicts and political instability in Pakistan is essential for social, economic, and political performance. The conflicts and political instability weaken the clean energy consumption and production performance, but it also declines the environmental regulations. Thus Pakistan needs to develop a strong political and institutional framework for environmental quality. Pakistan needs to take measures to improve governance and redesign the stable economic policies of energy and environment. Future studies can also focus on the impacts of numerous socioeconomic factors such as health, education, social security and instability, economic instability on clean energy consumption and $\mathrm{CO} 2$ emissions. Further empirical inquiry is required to seek better measures and channels through which political instability affects clean energy consumption and $\mathrm{CO} 2$ emissions. Future research should use a different measure of political instability in analysis for robust analysis.

\section{Ethical Approval: Not applicable}

Consent to Participate: I am free to contact any of the people involved in the research to seek further clarification and information

\section{Consent to Publish: Not applicable}

Authors Contributions: This idea was given by Muhammad Tayyab Sohail. Parvez Ahmed Shaikh, Muhammad Tayyab Sohail, and Muhammad Tariq Majeed analyzed the data and wrote the complete paper. While Zubaria Andlib read and approved the final version.

\section{Funding: Not applicable.}

Competing interests: The authors declare that they have no conflict of interest.

Availability of data and materials: The datasets used and/or analyzed during the current study are available from the corresponding author on reasonable request. 


\section{References}

Abbasi, F., \& Riaz, K. (2016). CO2 emissions and financial development in an emerging economy: an augmented VAR approach. Energy Policy, 90, 102-114.

Abdala, M. A. (2008). Governance of competitive transmission investment in weak institutional systems. Energy Economics, 30(4), 1306-1320.

Abid, M. (2016). Impact of economic, financial, and institutional factors on CO2 emissions: Evidence from SubSaharan Africa economies. Utilities Policy, 41, 85-94.

Adams, S., Adom, P. K., \& Klobodu, E. K. M. (2016). Urbanization, regime type and durability, and environmental degradation in Ghana. Environmental Science and Pollution Research, 23(23), 23825-23839.

Adams, S., Adom, P. K., \& Klobodu, E. K. M. (2016). Urbanization, regime type and durability, and environmental degradation in Ghana. Environmental Science and Pollution Research, 23(23), 23825-23839.

Ahmad, M., Khan, Z., Ur Rahman, Z., \& Khan, S. (2018). Does financial development asymmetrically affect CO2 emissions in China? An application of the nonlinear autoregressive distributed lag (NARDL) model. Carbon Management, 9(6), 631-644.

Ahmad, M., Khan, Z., Ur Rahman, Z., \& Khan, S. (2018). Does financial development asymmetrically affect CO2 emissions in China? An application of the nonlinear autoregressive distributed lag (NARDL) model. Carbon Management, 9(6), 631-644.

Ahmed, K., \& Long, W. (2013). An empirical analysis of CO2 emission in Pakistan using EKC hypothesis. Journal of International Trade Law and Policy. 12(2), 188-200.

Al-Mulali, U. (2014). Investigating the impact of nuclear energy consumption on GDP growth and CO2 emission: A panel data analysis. Progress in Nuclear Energy, 73, 172-178.

Al-Mulali, U., \& Ozturk, I. (2015). The effect of energy consumption, urbanization, trade openness, industrial output, and the political stability on the environmental degradation in the MENA (Middle East and North African) region. Energy, 84, 382-389.

Al-Mulali, U., \& Sab, C. N. B. C. (2012). The impact of energy consumption and CO2 emission on the economic growth and financial development in the Sub Saharan African countries. Energy, 39(1), 180-186.

Al-Mulali, U., Tang, C. F., \& Ozturk, I. (2015). Does financial development reduce environmental degradation? Evidence from a panel study of 129 countries. Environmental Science and Pollution Research, 22(19), 14891-14900.

Barrett, S., \& Graddy, K. (2000). Freedom, growth, and the environment. Environment and Development Economics, 5(4), 433-456.

Barrett, S., \& Graddy, K. (2000). Freedom, growth, and the environment. Environment and Development Economics, 5(4), 433-456.

Basarir, C. and Y.N. Çakir, Causal interactions between CO2 emissions, financial development, energy and tourism. Asian Economic and Financial Review, 2015. 5(11): p. 1227.

Battig, M. B., \& Bernauer, T. (2009). National institutions and global public goods: are democracies more cooperative in climate change policy?. International organization, 63(2), 281-308. 
Bhattacharya, M., Churchill, S. A., \& Paramati, S. R. (2017). The dynamic impact of renewable energy and institutions on economic output and $\mathrm{CO} 2$ emissions across regions. Renewable Energy, 111, 157-167.

Bohmelt, T., Boker, M., \& Ward, H. (2016). Democratic inclusiveness, climate policy outputs, and climate policy outcomes. Democratization, 23(7), 1272-1291.

Burke, M. J., \& Stephens, J. C. (2018). Political power and renewable energy futures: A critical review. Energy Research \& Social Science, 35, 78-93.

Burnell, P. (2012). Democracy, democratization and climate change: complex relationships. Democratization, 19(5), 813-842.

Carlsson, F., \& Lundström, S. (2003). The effects of economic and political freedom on CO2 emissions. Economic Studies, Department of Economics, School of Economics and Commercial Law, Göteborg University: Gothenburg, Sweden, 79.

Congleton, R. D. (1992). Political institutions and pollution control. The Review of Economics and Statistics, 412421.

Deacon, R. T. (2002). Dictatorship, Democracy and the Provision of Public Goods. In Department of Economics, University of California at Santa Barbara, Working Paper 11-99. Economics, 37, 1979-1990.

Ding, T., Ning, Y., \& Zhang, Y. (2018). The contribution of China's bilateral trade to global carbon emissions in the context of globalization. Structural Change and Economic Dynamics, 46, 78-88.

Dogan, E., \& Seker, F. (2016). An investigation on the determinants of carbon emissions for OECD countries: empirical evidence from panel models robust to heterogeneity and cross-sectional dependence. Environmental Science and Pollution Research, 23(14), 14646-14655.

Dogan, E., \& Turkekul, B. (2016). CO 2 emissions, real output, energy consumption, trade, urbanization and financial development: testing the EKC hypothesis for the USA. Environmental Science and Pollution Research, 23(2), 1203-1213.

Farhani, S. and I. Ozturk, Causal relationship between CO 2 emissions, real GDP, energy consumption, financial development, trade openness, and urbanization in Tunisia. Environmental Science and Pollution Research, 2015. 22(20): p. 15663-15676.

Farhani, S., \& Ozturk, I. (2015). Causal relationship between CO 2 emissions, real GDP, energy consumption, financial development, trade openness, and urbanization in Tunisia. Environmental Science and Pollution Research, 22(20), 15663-15676.

Gani, A. (2012). The relationship between good governance and carbon dioxide emissions: Evidence from developing economies. Journal of Economic Development, 37(1), 77.

Gani, A., 2012. The relationship between good governance and carbon dioxide emission: evidence from developing economies. J. Econ. Dev. 37, 77e93.

Goel, R. K., Herrala, R., \& Mazhar, U. (2013). Institutional quality and environmental pollution: MENA countries versus the rest of the world. Economic Systems, 37(4), 508-521.

Gokmenoglu, K. K., \& Sadeghieh, M. (2019). Financial development, CO2 emissions, fossil fuel consumption and economic growth: The case of Turkey. Strategic Planning for Energy and the Environment, 38(4), 7-28. 
Grossman, G. M., \& Krueger, A. B. (1995). Economic growth and the environment. The Quarterly Journal of Economics, 110(2), 353-377.

Haseeb, A., Xia, E., Baloch, M. A., \& Abbas, K. (2018). Financial development, globalization, and CO 2 emission in the presence of EKC: evidence from BRICS countries. Environmental Science and Pollution Research, 25(31), 31283-31296.

Haseeb, M., Wattanapongphasuk, S., \& Jermsittiparsert, K. (2019). Financial Development, Market Freedom, Political Stability, Economic Growth and C [O. sub. 2] Emissions: An Unexplored Nexus in ASEAN Countries. Contemporary Economics, 13(3), 363-375.

Ibrahim, M. H., \& Law, S. H. (2016). Institutional Quality and CO2 Emission-Trade Relations: Evidence from SubSaharan Africa. South African Journal of Economics, 84(2), 323-340.

Javid, M., \& Sharif, F. (2016). Environmental Kuznets curve and financial development in Pakistan. Renewable and Sustainable Energy Reviews, 54, 406-414.

Kasperowicz, R. (2015). Economic growth and CO2 emissions: The ECM analysis. Journal of International Studies, 8(3), 91-98.

Khan, D., \& Ullah, A. (2019). Testing the relationship between globalization and carbon dioxide emissions in Pakistan: does environmental Kuznets curve exist?. Environmental Science and Pollution Research, 26(15), 15194-15208.

Khan, M. I., Teng, J. Z., \& Khan, M. K. (2020). The impact of macroeconomic and financial development on carbon dioxide emissions in Pakistan: evidence with a novel dynamic simulated ARDL approach. Environmental Science and Pollution Research, 27(31), 39560-39571.

Komal, R., \& Abbas, F. (2015). Linking financial development, economic growth and energy consumption in Pakistan. Renewable and Sustainable Energy Reviews, 44, 211-220.

Lahiani, A. (2020). Is financial development good for the environment? An asymmetric analysis with CO 2 emissions in China. Environmental Science and Pollution Research, 27(8), 7901-7909.

Lau, L.S., Choong, C.K., Eng, Y.K., 2014. Carbon dioxide emission, institutional quality, and economic growth: empirical evidence in Malaysia. Renew. Energy 68, 276e281

Lee, J.-M., K.-H. Chen, and C.-H. Cho, The relationship between CO2 emissions and financial development: evidence from OECD countries. The Singapore Economic Review, 2015. 60(05): p. 1550117.

Majeed, M. T., \& Luni, T. (2019). Renewable energy, water, and environmental degradation: A global panel data approach. Pakistan Journal of Commerce and Social Sciences, 13(3), 749-778.

Majeed, M. T., \& Mazhar, M. (2020). Reexamination of Environmental Kuznets Curve for Ecological Footprint: The Role of Biocapacity, Human Capital, and Trade. Pakistan Journal of Commerce and Social Sciences, 14(1), 202-254.

Midlarsky, M. I. (1998). Democracy and the environment: an empirical assessment. Journal of Peace Research, 35(3), 341-361.

Midlarsky, M. I. (1998). Democracy and the environment: an empirical assessment. Journal of Peace Research, 35(3), 341-361. 
Mugableh, M.I., Economic growth, $\mathrm{CO} 2$ emissions, and financial development in Jordan: Equilibrium and dynamic causality analysis. International Journal of Economics and Finance, 2015. 7(7): p. 98.

Nasir, M., \& Rehman, F. U. (2011). Environmental Kuznets curve for carbon emissions in Pakistan: an empirical investigation. Energy Policy, 39(3), 1857-1864.

Ozturk, I., \& Acaravci, A. (2013). The long-run and causal analysis of energy, growth, openness and financial development on carbon emissions in Turkey. Energy Economics, 36, 262-267.

Ozturk, I., \& Acaravci, A. (2013). The long-run and causal analysis of energy, growth, openness and financial development on carbon emissions in Turkey. Energy Economics, 36, 262-267.

Ozturk, I., \& Al-Mulali, U. (2015). Investigating the validity of the environmental Kuznets curve hypothesis in Cambodia. Ecological Indicators, 57, 324-330.

Panayotou, T. (1997). Demystifying the environmental Kuznets curve: turning a black box into a policy tool. Environment and Development Economics, 465-484.

Pata, U. K. (2018). Renewable energy consumption, urbanization, financial development, income and CO2 emissions in Turkey: testing EKC hypothesis with structural breaks. Journal of Cleaner Production, 187, 770-779.

Purcel, A. A. (2019). Does political stability hinder pollution? Evidence from developing states. Economic Research Guardian, 9(2), 75-98.

Purcel, A. A. (2019). Does political stability hinder pollution? Evidence from developing states. Economic Research Guardian, 9(2), 75-98.

Raleigh, C., \& Urdal, H. (2007). Climate change, environmental degradation and armed conflict. Political geography, 26(6), 674-694.

Rizk, R., Slimane, M. Ben, 2018. Modelling the relationship between poverty, environment, and institutions: a panel data study. Environ. Sci. Pollut. Res. 25 (31), 31459e31473. https://doi.org/10.1007/s11356-018-3051-6

Samimi, A. J., Ahmadpour, M., \& Ghaderi, S. (2012). Governance and environmental degradation in MENA region. Procedia-Social and Behavioral Sciences, 62, 503-507.

Sarkodie, S. A., \& Adams, S. (2018). Renewable energy, nuclear energy, and environmental pollution: accounting for political institutional quality in South Africa. Science of the total environment, 643, 1590-1601.

Sequeira, T. N., \& Santos, M. S. (2018). Renewable energy and politics: A systematic review and new evidence. Journal of Cleaner Production, 192, 553-568.

Shahbaz, M., Nasir, M. A., \& Roubaud, D. (2018). Environmental degradation in France: the effects of FDI, financial development, and energy innovations. Energy Economics, 74, 843-857.

Shahbaz, M., Tiwari, A. K., \& Nasir, M. (2013). The effects of financial development, economic growth, coal consumption and trade openness on CO2 emissions in South Africa. Energy Policy, 61, 1452-1459.

Shahzad, S. J. H., Kumar, R. R., Zakaria, M., \& Hurr, M. (2017). Carbon emission, energy consumption, trade openness and financial development in Pakistan: a revisit. Renewable and Sustainable Energy Reviews, 70, 185-192. 
Sharma, S. S. (2011). Determinants of carbon dioxide emissions: empirical evidence from 69 countries. Applied Energy, 88(1), 376-382.

545 Shoaib, H. M., Rafique, M. Z., Nadeem, A. M., \& Huang, S. (2020). Impact of financial development on CO 2 emissions: A comparative analysis of developing countries (D 8) and developed countries (G 8). Environmental Science and Pollution Research, 1-15.

Tamazian, A., Chousa, J. P., \& Vadlamannati, K. C. (2009). Does higher economic and financial development lead to environmental degradation: evidence from BRIC countries. Energy policy, 37(1), 246-253.

Torras, M., \& Boyce, J. K. (1998). Income, inequality, and pollution: a reassessment of the environmental Kuznets curve. Ecological Economics, 25(2), 147-160.

Ullah, S., Ozturk, I., Usman, A., Majeed, M. T., \& Akhtar, P. (2020). On the asymmetric effects of premature deindustrialization on $\mathrm{CO} 2$ emissions: evidence from Pakistan. Environmental Science and Pollution Research, 1-11.

Ullah, S., Ozturk, I., Usman, A., Majeed, M. T., \& Akhtar, P. (2020). On the asymmetric effects of premature deindustrialization on $\mathrm{CO} 2$ emissions: evidence from Pakistan. Environmental Science and Pollution Research, 1-11.

Uzar, U. (2020). Political economy of renewable energy: Does institutional quality make a difference in renewable energy consumption?. Renewable Energy, 155, 591-603.

Wawrzyniak, D., \& Doryń, W. (2020). Does the quality of institutions modify the economic growth-carbon dioxide emissions nexus? Evidence from a group of emerging and developing countries. Economic ResearchEkonomska Istraživanja, 33(1), 124-144.

Xu, Z., Baloch, M. A., Meng, F., Zhang, J., \& Mahmood, Z. (2018). Nexus between financial development and CO 2 emissions in Saudi Arabia: analyzing the role of globalization. Environmental Science and Pollution Research, 25(28), 28378-28390.

566 Zhang, Y. J. (2011). The impact of financial development on carbon emissions: An empirical analysis in China. Energy policy, 39(4), 2197-2203. 